\title{
Variation in growth and survival among European provenances of Pinus sylvestris in a 30-year-old experiment
}

Received: 29 April 2015; Accepted: 9 September 2015

\begin{abstract}
Provenance trials with forest trees provide valuable information about growth and adaptability of populations often transferred over large geographical and climatic distances. In this study we evaluated growth and survival of 19 Scots pine (Pinus sylvestris L.) populations representing most of the natural range of the species in Europe, growing in a 30-year-old provenance trial in the northeastern Poland. We used cluster analysis to investigate differentiation among those populations in growth and survival. We also used published data on needle morphology and allozyme and DNA marker variation for those same populations to compare groupings of populations based on growth and needle traits and markers.
\end{abstract}

We found significant variation among tested populations in all investigated traits - the largest variation was found for stand volume which integrates information on growth and survival. Variation in growth traits was related to the latitude of population origin with populations from the latitudinal band between $49^{\circ} \mathrm{N}$ and $54^{\circ} \mathrm{N}$ showing the best performance. Populations originating from both north and south off of that region showed lower productivity, which for southern provenances resulted from their particularly low survival, reflecting the lack of adaptation to the environment of the research site. Grouping of populations based on growth traits revealed three clusters corresponding to the three latitudinal regions - northern, central and southern. Needle morphological traits were not appropriate as markers of productivity. Clustering of populations based on needle morphology, and especially based on biochemical and molecular markers, did not correspond to the grouping based on growth traits.

Keywords: productivity, provenance test, provenance transfer, IUFRO 1982

Addresses: W. Barzdajn, W. Kowalkowski, Department of Silviculture, Faculty of Forestry, Poznań University of Life Sciences, ul. Wojska Polskiego 69 60-625 Poznań, e-mail: barzdajn@up.poznan.pl; wojkowal@up.poznan.pl

D. J. Chmura, Institute of Dendrology, Polish Academy of Sciences, ul. Parkowa 5, 62-035 Kórnik, Poland, e-mail:djchmura@man.poznan.pl 


\section{Introduction}

In large parts of eastern Europe Scots pine (Pinus sylvestris L.) is the most important commercial forest tree species. Within its wide natural range in the Euroasiatic continent the species shows large variability of its adaptation and growth features (Białobok, 1970; Boratyński, 1993; Broda, 1993).

Provenance tests with Scots pine date back to as early as the 19th century. Few of those tests would meet the present-day statistical standards required for field experimentation, but frequently the progeny of one stand (provenance) was planted at several experimental sites. Most of those early experiments were limited to the scale of national tests. Results of those tests were published in the collective monographs (Giertych, 1979, 1997; Giertych \& Oleksyn, 1992; Shutyaev \& Giertych, 2003). The wide geographical range of Scots pine, its broad ecological amplitude, and only limited knowledge of the intraspecies variation have led to the establishment of several series of international provenance trials. The International Union of Forest Research Organizations (IUFRO) organised and supervised these projects. The last such a series of provenance trials with Scots pine was established in 1982 (SP IUFRO 1982) with at least 10 experimental sites planted throughout Europe, and five of those sites were established in Poland (Oleksyn, 1988; Oleksyn \& Rachwał, 1994).

Previous reports from this series of provenance experiments provide information on variation in growth, survival, phenology, growth rhythms, productivity, stem form, needle morphology and biomass allocation (Androsiuk et al., 2011; Andrzejewski et al., 1994; Barzdajn, 2000, 2008; Kohlstock \& Schneck, 1998; Matras, 1998; Oleksyn et al., 1992, 1999; 2000; 2001; Stephan \& Liesebach, 1996). Genetic diversity among those populations was investigated with biochemical (Prus-Głowacki, 1998) and molecular markers (Androsiuk \& Urbaniak, 2014), but inconclusive results have been found regarding the relationship between allozyme variation and growth traits (Barzdajn, 2008).

In this study we examined variability of adaptation and growth traits among Scots pine populations at one of the IUFRO 1982 experimental sites in Supraśl, Poland at the age of 30 years. Because the relative performance of provenances may vary not only by site (genotype $\times$ site interaction), but also over time (genotype $\times$ time interaction) it is important to evaluate provenance tests on regular basis. Results obtained at the later ages are more meaningful to practical forestry than those at early ages. In our analysis we also used data and results published for variation in enzymatic (Prus-Głowacki, 1998) and DNA markers (Androsiuk \& Urbaniak,
2014) for this same set of populations with the aim to compare patterns of differentiation among populations based on growth traits with those obtained using biochemical and molecular markers. We also correlated the results of our growth analysis with the previously reported data on needle morphology variation (Androsiuk et al., 2011) in a search for morphological markers that may be associated with growth traits.

\section{Material and methods}

The study site is one of five test sites of the IUFRO 1982 provenance experimental series established in Poland. Twenty progenies (mostly provenances) of Scots pine are tested at each location. On individual experimental sites local populations or the so-called standards are additionally represented. A detailed description of the tested populations was given in earlier papers by Oleksyn (1988) and Giertych and Oleksyn (1992).

The experimental site in Supraśl was established after clear-cutting of a pine stand at the $1^{\text {st }}$ class of site index and total volume of $373 \mathrm{~m}^{3} \mathrm{ha}^{-1}$. Soil originated from light-clay sand and was described as clavic luvisol (World Reference Base, 2006). Forest site type, according to the Polish forest site classification, was described as fresh mixed coniferous site. Potential vegetation association is Querco roboris - Pinetum.

Detailed methodological assumptions and earlier results from the experimental site in Supraśl were presented in earlier reports (Andrzejewski et al., 1994; Barzdajn, 2000, 2008). Each provenance-plot was a rectangle of the size $18 \times 16.5 \mathrm{~m}$, and was planted with 132 seedlings at the $1,5 \times 1,5 \mathrm{~m}$ spacing. The number of replications within a site varied from 2 to 5 for each provenance, and the distribution of provenance plots was random. The Lampertheim provenance was represented on a single plot only, and was excluded from further analyses. Only natural regeneration of pine and other tree species has been removed from the experimental site.

A list of tested provenances is given in the Table 1 . In addition to the core set of populations (Oleksyn, 1988) the progeny of a local population (Supraśl mt., Table 1) was planted at the site. Seedlings of this population were a year younger than the others at planting, and for that reason it was also excluded from statistical analyses.

After the completion of the vegetation season in 2012 breast height diameters $\left(D_{1.3}\right)$ were measured on all trees, while tree height $(\mathrm{H})$ was measured on 16 - 20 trees for each population. Based on these data the parameters $a$ and $b$ of height curves were 
Table 1. Mean values of breast high diameter $\left(\mathrm{D}_{1.3}\right)$, tree height $(H)$, stem slenderness $(\mathrm{D} / \mathrm{H})$, survival rate $(\mathrm{S})$, basal area (G) and stand volume (V) for the Scots pine populations at the Supraśl site recorded in 2012. Values followed with the same lower-case letters do not differ significantly in a Tukey's test at the $\alpha=0.05$. Provenance IDs and geographic coordinates are given in accordance with Oleksyn 1988

\begin{tabular}{|c|c|c|c|c|c|c|c|c|c|}
\hline Provenance ID & $\begin{array}{l}\text { Latit. } \\
\left({ }^{\circ} \mathrm{N}\right)\end{array}$ & $\begin{array}{c}\text { Longit. } \\
\left({ }^{\circ} \mathrm{E}\right)\end{array}$ & $\begin{array}{c}\text { No. of } \\
\text { replications } \\
\text { within a site }\end{array}$ & $\mathrm{D}_{1.3}(\mathrm{~cm})$ & $\mathrm{H}(\mathrm{m})$ & $\begin{array}{c}\mathrm{D} / \mathrm{H} \\
(\mathrm{cm} / \mathrm{m})\end{array}$ & S (\%) & $\mathrm{G}\left(\mathrm{m}^{2} \mathrm{ha}^{-1}\right)$ & $\mathrm{V}\left(\mathrm{m}^{3} \mathrm{ha}^{-1}\right)$ \\
\hline 1.Roščinskaja Dača & $60^{\circ} 15^{\prime}$ & $29^{\circ} 54^{\prime}$ & 4 & $13.10 \mathrm{a}$ & $13.01 \mathrm{ab}$ & $1.01 \mathrm{abc}$ & $55.49 \mathrm{e}$ & 35.39 bcdef & $282.83 \mathrm{bcd}$ \\
\hline 2. Kondežskoe & $59^{\circ} 58^{\prime}$ & $33^{\circ} 30^{\prime}$ & 5 & $13.98 \mathrm{ab}$ & $14.46 \mathrm{def}$ & $0.97 \mathrm{a}$ & 49.39 cde & 36.03 bcdef & 296.84 bcde \\
\hline 3. Serebryanskoe & $58^{\circ} 50^{\prime}$ & $29^{\circ} 07^{\prime}$ & 4 & $14.38 \mathrm{abc}$ & $14.86 \mathrm{efg}$ & $0.97 \mathrm{a}$ & $53.60 \mathrm{de}$ & 40.84 cdefgh & 352.78 cdef \\
\hline 4. Silene & $55^{\circ} 45^{\prime}$ & $26^{\circ} 40^{\prime}$ & 4 & 16.58 bcde & 15.96 hij & $1.04 \mathrm{abcd}$ & 45.27 cde & 45.23 cdefgh & 405.56 defg \\
\hline 5. Miłomłyn & $53^{\circ} 34^{\prime}$ & $20^{\circ} 00^{\prime}$ & 5 & 17.11 bcde & $17.43 \mathrm{kmn}$ & $0.98 \mathrm{a}$ & $51.21 \mathrm{de}$ & $55.20 \mathrm{gh}$ & $518.52 \mathrm{~g}$ \\
\hline 6. Supraśl & $53^{\circ} 12^{\prime}$ & $23^{\circ} 22^{\prime}$ & 3 & 16.41 bcde & $16.58 \mathrm{jkl}$ & $0.99 \mathrm{abc}$ & $50.00 \mathrm{cde}$ & 49.68 defgh & 440.07 defg \\
\hline 7. Spała & $51^{\circ} 37^{\prime}$ & $20^{\circ} 12^{\prime}$ & 4 & 16.26 bcde & 15.64 ghi & $1.04 \mathrm{abcd}$ & $53.41 \mathrm{de}$ & $52.32 \mathrm{gh}$ & $473.74 \mathrm{fg}$ \\
\hline 8. Rychtal & $51^{\circ} 08^{\prime}$ & $17^{\circ} 55^{\prime}$ & 5 & $17.86 \mathrm{e}$ & $17.62 \mathrm{n}$ & $1.01 \mathrm{abc}$ & 47.88 cde & $55.92 \mathrm{~h}$ & $539.26 \mathrm{~g}$ \\
\hline 9. Bolewice & $52^{\circ} 24^{\prime}$ & $16^{\circ} 03^{\prime}$ & 2 & 17.32 bcde & $17.44 \mathrm{klmn}$ & $0.99 \mathrm{abcd}$ & $43.18 \mathrm{cde}$ & 47.95 cdefgh & 420.88 cdefg \\
\hline 10. Neuhaus & $53^{\circ} 02^{\prime}$ & $13^{\circ} 54^{\prime}$ & 5 & $17.59 \mathrm{de}$ & $17.51 \mathrm{mn}$ & $1.00 \mathrm{ab}$ & 43.48 cde & $49.24 \mathrm{fgh}$ & $455.82 \mathrm{fg}$ \\
\hline 11. Betzhorn & $52^{\circ} 30^{\prime}$ & $10^{\circ} 30^{\prime}$ & 3 & 16.74 bcde & $16.39 \mathrm{ijl}$ & $1.02 \mathrm{abcd}$ & 30.81 bcde & 32.43 bcde & 291.36 bcde \\
\hline 13. Ardenns & $50^{\circ} 46^{\prime}$ & $4^{\circ} 26^{\prime}$ & 4 & 17.32 bcde & $17.32 \mathrm{kmn}$ & $1.00 \mathrm{abc}$ & 44.89 cde & 47.83 defgh & 428.37 defg \\
\hline 14. Haguenau & $48^{\circ} 49^{\prime}$ & $7^{\circ} 46^{\prime}$ & 4 & $18.33 \mathrm{e}$ & $16.34 \mathrm{ij}$ & $1.12 \mathrm{bcd}$ & $35.98 \mathrm{cde}$ & 40.68 cdefg & 362.46 cdef \\
\hline 15. Sumpberget & $60^{\circ} 11^{\prime}$ & $15^{\circ} 52^{\prime}$ & 4 & $13.10 \mathrm{a}$ & $13.38 \mathrm{abc}$ & $0.98 \mathrm{ab}$ & 51.14 cde & $32.64 \mathrm{bcd}$ & 248.32 bc \\
\hline 16. Zahorie & $48^{\circ} 46^{\prime}$ & $17^{\circ} 03^{\prime}$ & 5 & $17.52 \mathrm{de}$ & $15.17 \mathrm{fgh}$ & $1.15 \mathrm{~d}$ & $28.03 \mathrm{bc}$ & $31.43 \mathrm{bc}$ & $256.30 \mathrm{bc}$ \\
\hline 17. Pornóapáti & $47^{\circ} 20^{\prime}$ & $16^{\circ} 28^{\prime}$ & 4 & 17.39 cde & $16.77 \mathrm{jklm}$ & $1.04 \mathrm{abcd}$ & 44.70 cde & 49.15 efgh & 439.56 efg \\
\hline 18. Maočnica & $43^{\circ} 10^{\prime}$ & $19^{\circ} 30^{\prime}$ & 4 & $14.12 \mathrm{ab}$ & 13.74 bcd & $1.03 \mathrm{abcd}$ & $29.17 \mathrm{bcd}$ & $21.71 \mathrm{ab}$ & $174.24 \mathrm{ab}$ \\
\hline 19. Prusačka Rijeka & $44^{\circ} 06^{\prime}$ & $17^{\circ} 21^{\prime}$ & 4 & 16.24 bcde & $14.16 \mathrm{cde}$ & $1.14 \mathrm{~cd}$ & $11.55 \mathrm{ab}$ & $10.68 \mathrm{a}$ & $84.09 \mathrm{a}$ \\
\hline 20. Catacik & $40^{\circ} 00^{\prime}$ & $31^{\circ} 10^{\prime}$ & 4 & $14.76 \mathrm{abcd}$ & $12.80 \mathrm{a}$ & $1.15 \mathrm{~d}$ & $7.20 \mathrm{a}$ & $06.13 \mathrm{a}$ & $44.61 \mathrm{a}$ \\
\hline Supraśl m*. & $53^{\circ} 12^{\prime}$ & $23^{\circ} 22^{\prime}$ & 4 & 15.65 & 15.55 & 1.01 & 52.46 & 47.33 & 412.37 \\
\hline 14. Lampertheim* & $50^{\circ} 00^{\prime}$ & $10^{\circ} 00^{\prime}$ & 1 & 17.85 & 16.04 & 1.11 & 43.94 & 51.53 & 429.63 \\
\hline mean & & & & 16.17 & 15.63 & 1.04 & 41.56 & 39.97 & 350.36 \\
\hline St. dev. & & & & 1.59 & 1.52 & 0.06 & 13.03 & 13.46 & 130.25 \\
\hline Variation coeff. (\%) & & & & 9.83 & 9.70 & 5.96 & 31.36 & 33.66 & 37.18 \\
\hline
\end{tabular}

* denotes populations excluded from statistical analyses.

determined separately for each population applying the Näslund parabola:

$$
H=\left(\frac{D_{1.3}}{a+b D_{1.3}}\right)^{2}+1.3
$$

This formula was used to estimate height of all remaining trees. Next, on the basis of $\mathrm{D}_{1.3}$ and the tree height, the volume of whole trees was obtained from the growth and yield tables (Czuraj, 1991). From the distribution of $\mathrm{D}_{1.3}$ on each plot the following parameters were calculated: basal area $\left(\mathrm{G} \mathrm{m}^{2} \mathrm{ha}^{-1}\right)$, the mean quadratic diameter from the basal area $\left(\mathrm{qD}_{1.3}\right)$ mean tree height $(\mathrm{H} \mathrm{m})$ and stand volume per hectare $\left(\mathrm{V} \mathrm{m}^{3} \mathrm{ha}^{-1}\right)$. Based on the number of trees the survival rate (S) was calculated in percent and the results were arc-sine converted in order to standardize variances within provenances. Stem slenderness was calculated as a $\mathrm{D}_{1.3} / \mathrm{H}$ ratio.

Results were subjected to the analysis of variance. The mathematical model for a single factor completely randomized design was applied, which is appropriate at varying number of provenance replications:

$$
\mathrm{y}_{\mathrm{ij}}=\mu+\mathrm{a}_{\mathrm{i}}+\mathrm{e}_{\mathrm{ij}}
$$

where:

$y_{i j}$ - value of a trait of population $i$ on plot $j$,

$\mu$ - total arithmetic mean,

$a_{i}$ - the effect of population $i$,

$\mathrm{e}_{i j}$ - error term.

In cases when the result of the analysis of variance made it possible to reject the hypothesis about a lack of differences among provenances, Tukey's test was applied in further comparisons.

In our analysis we used the results of enzyme polymorphism variability reported by Prus-Głowacki (1998) for the seven enzymatic loci on the same set of provenances at the other experimental site of the same IUFRO 1982 series in the Institute of Dendrology in Kórnik, Poland. We also used the results of needle morphology variation analyses conducted at the site in Supraśl (Androsiuk et al., 2011). Values of the parameters and traits reported for individual provenances in those papers were correlated with the growth traits we measured in our study and with geographical coordinates (in radians) of the provenances. The following symbols and abbreviations were used to denote individual characteristics: $\phi$ - latitude; $\lambda$ - longitude; $\mathrm{A} / \mathrm{L}$ - number of alleles in per locus; Ho - observed heterozygosity; F - fixation index; 


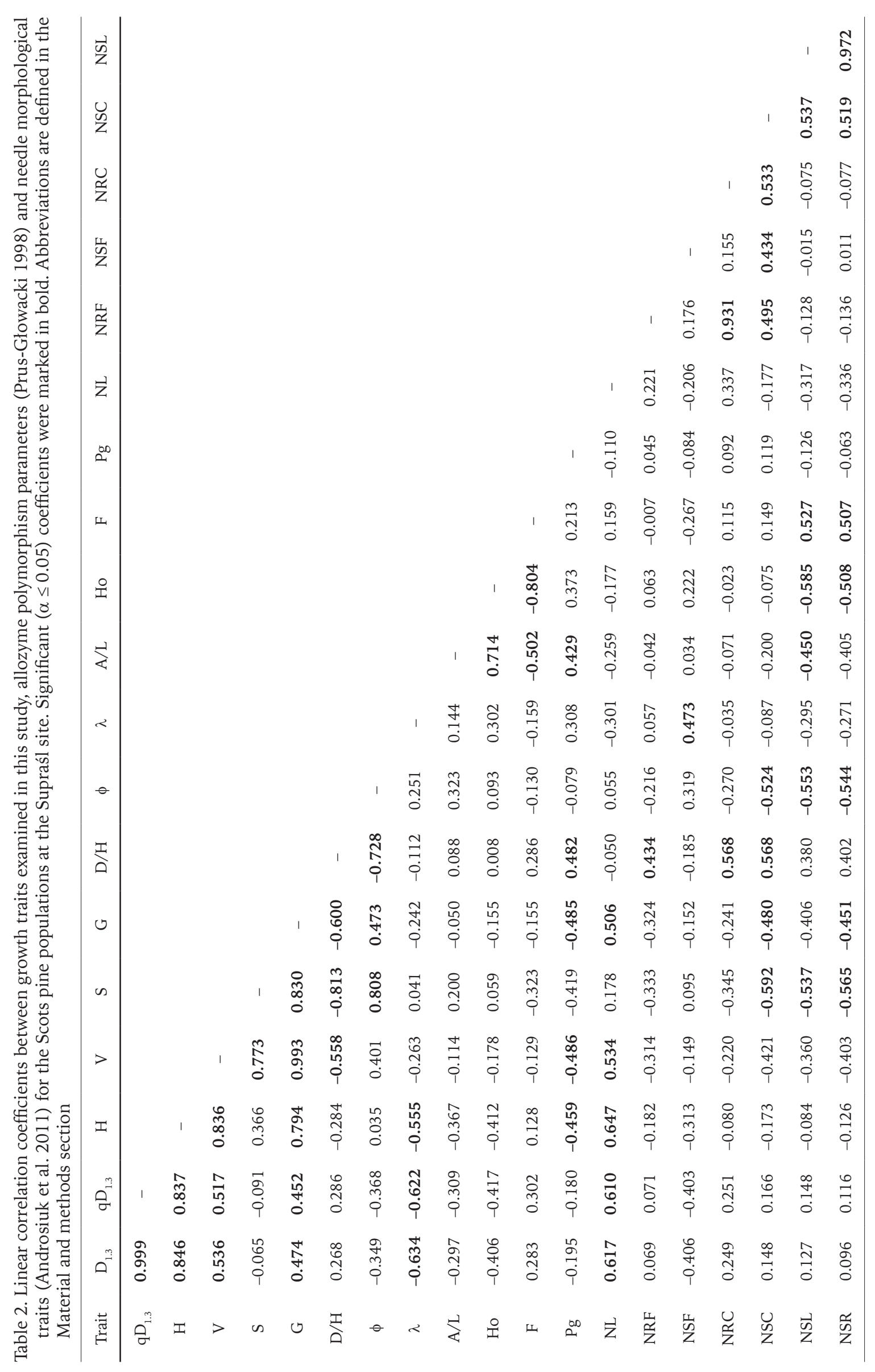


Pg - proportion of polymorphic loci (Prus-Głowacki, 1998); NL - needle length; NRF - number of stomatal rows on the flat side of needles; NSF - number of stomata per $2 \mathrm{~mm}$ needle length on the flat side of needles; NRC - number of stomatal rows on the convex side of needles; NSC - number of stomata per $2 \mathrm{~mm}$ needle length on the convex side of needles; NSL - number of serrations per $2 \mathrm{~mm}$ left margin of needles; NSR - number of serrations per $2 \mathrm{~mm}$ right margin of needles (Androsiuk et al., 2011). In cases where correlation coefficients were significant, the appropriate regression analysis (linear or nonlinear) was performed.

In order to group the compared populations we performed the cluster analysis using the Ward method on the standardized data for diameter, tree height and survival. We also performed similar clustering based on enzyme variation parameters (PrusGłowacki, 1998), and needle morphological traits (Androsiuk et al., 2011). Subsequently we compared results of clustering of populations obtained using these various traits and parameters with the UPGMA grouping based on Nei's genetic distance reported in Androsiuk and Urbaniak (2014) for the RAPD and ISJ markers.

\section{Results}

All traits we measured at the site in Supraśl significantly differentiated the set of examined provenances (Table 1). Variation was the greatest for the stand volume per hectare, basal area and survival rate, for which the values of variation coefficient exceeded 30 $\%$ (Table 1). Diversity in these traits was even more marked when we compared absolute values for individual provenances. In terms of stand volume the Rychtal and Miłomłyn populations exceeded $500 \mathrm{~m}^{3}$ $\mathrm{ha}^{-1}$, while the Prusačka Rijeka and Catacik populations did not reach $100 \mathrm{~m}^{3} \mathrm{ha}^{-1}$ (Table 1). The relationship between stand volume and the geographical location of the population origin was curvilinear and consistent with the graph of quadratic parabola (Fig. 1). Similar relationships were found for tree height and $\mathrm{D}_{1.3}$ (Fig. 1). These relationships showed a very good fit as their coefficients of determination ranged from $R^{2}=0.73$ to $R^{2}=0.85$. The highest values of growth traits of trees, and thus parabola vertexes, were observed for the populations originating from the latitudinal zone between $49^{\circ} \mathrm{N}$ and $54^{\circ} \mathrm{N}$ (re-calculated from radians). Populations originating from locations situated further north or south from that zone reached smaller tree dimensions and lower values of stand volume. The relationships between growth traits and longitude were not as marked as for the latitude. For example, the mean tree height showed a decreasing trend with increasing longitude
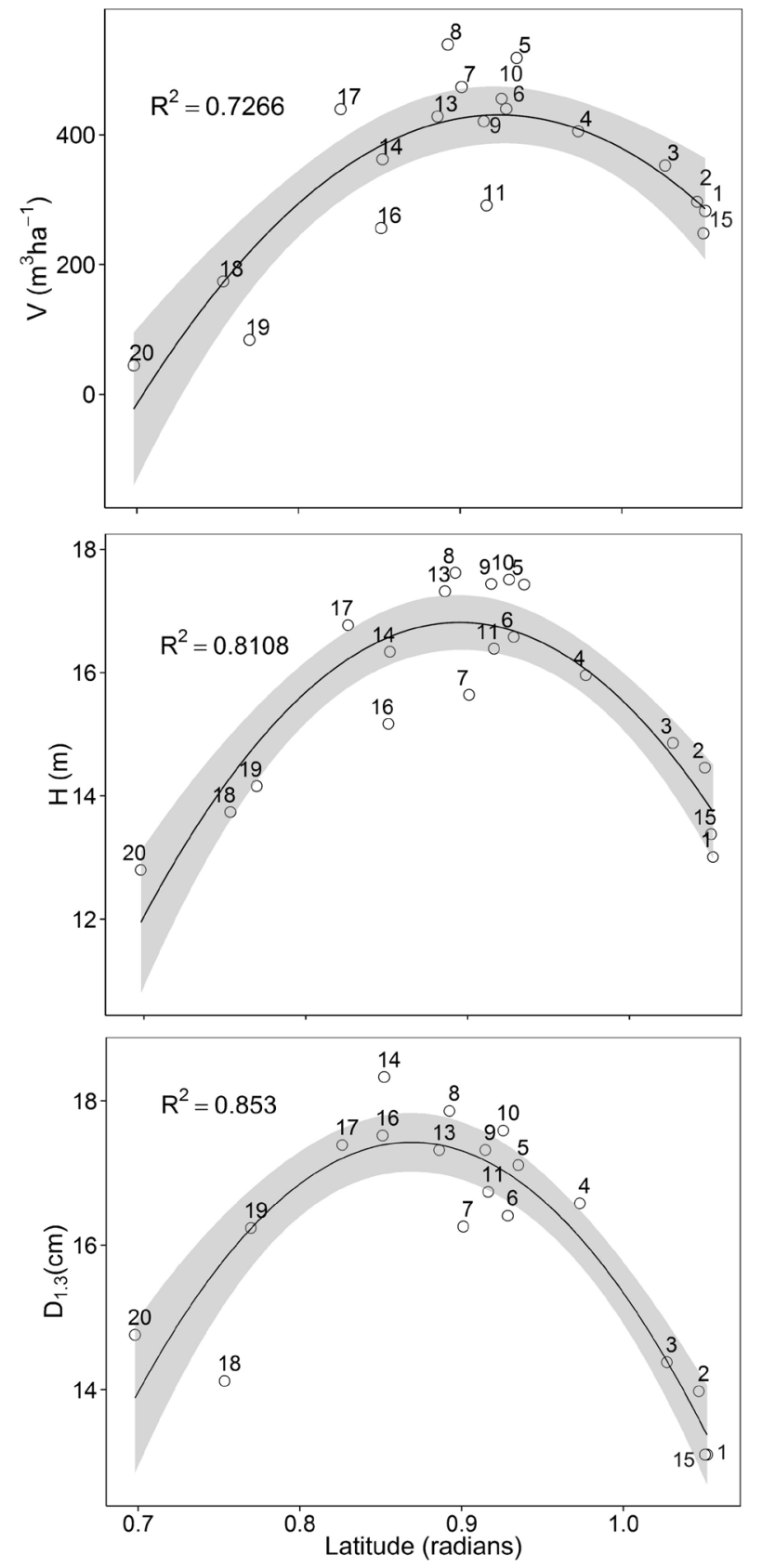

Fig. 1. Relationship between latitude of provenance and stand volume $(\mathrm{V})$, tree height $(\mathrm{H})$ and diameter $\left(\mathrm{D}_{1.3}\right)$ for 19 populations of Scots pine examined at the site in Supraśl. Shading indicates $95 \%$ confidence region for regression line

of the population origin (Fig. 2), but a respective coefficient of determination had a relatively low value $\left(\mathrm{R}^{2}=0.32\right)$.

In the case of survival rate a high variation among the compared populations resulted from very low survival of the Turkish provenance Catacik (7.2\%) and the Bosnian provenance Prusačka Rijeka (11.55\%). These two populations showed practically no adaptation to the environmental conditions of the Supraśl site. In contrast, the Russian provenances 

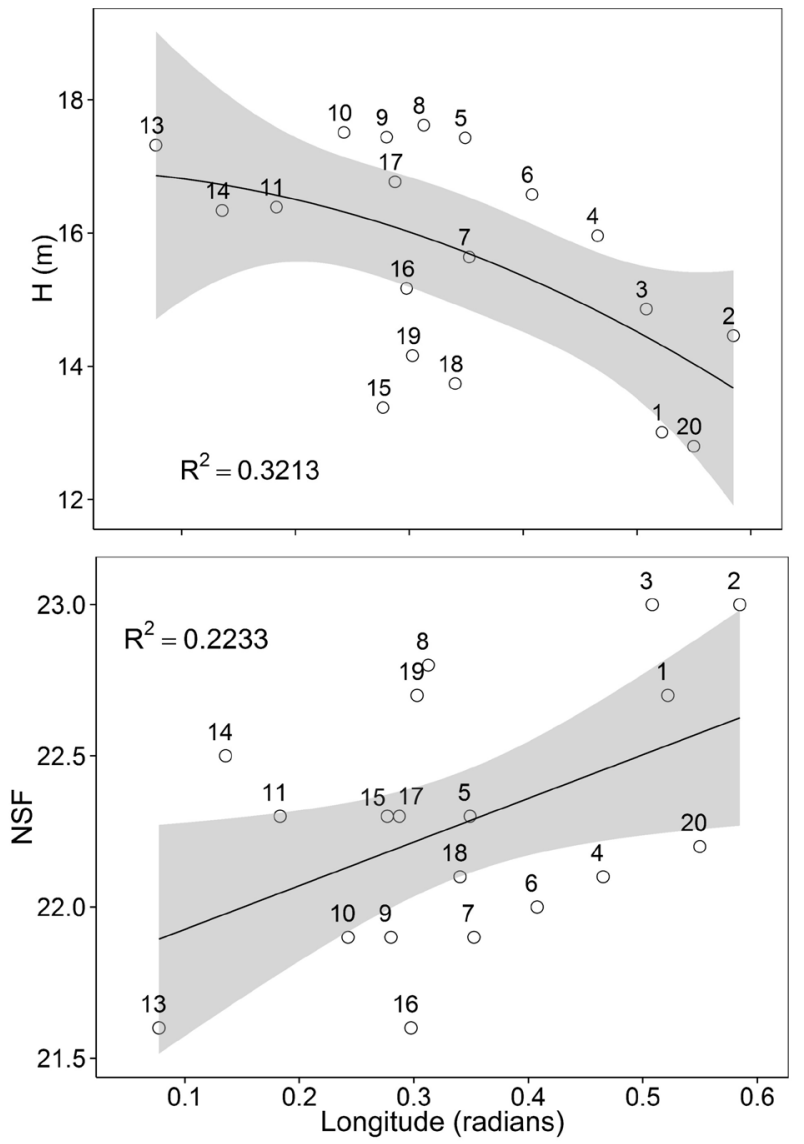

Fig. 2. Relationship between longitude of provenance and tree height $(\mathrm{H})$ and the number of stomata per $2 \mathrm{~mm}$ on the flat site of a needle (NSF) for 19 populations of Scots pine examined at the site in Supraśl. Shading indicates $95 \%$ confidence region for regression line

from the vicinity of St. Petersburg, and the Swedish provenance Sumpberget had high survival rates, and despite of having relatively short and thin trees, have accumulated the stand volumes that were close to the mean of the experimental site $\left(350.36 \mathrm{~m}^{3} \mathrm{ha}^{-1}\right.$, Table 1). Overall, the highest survival rate was recorded for the provenances Roščinskaja Dača (55.5\%) and Serebryanskoe (53.6\%), whereas the highest survival among the Polish populations was recorded for the provenance Spała (53.4\%, Table 1). Among the traits we measured at the study site the survival rate and stem slenderness showed the strongest correlations with the latitude of population origin, but in the opposite directions (Table 2). Survival increased curvilinearly $\left(\mathrm{R}^{2}=0.75\right.$, not shown), and stem slenderness decreased linearly $\left(\mathrm{R}^{2}=0.52\right.$, not shown) from southern to northern populations.

Among the measures of genetic variability the significant correlations with growth traits were observed only for the proportion of polymorphic loci (Table 2). It was negatively correlated with tree height, basal area and stand volume, whereas positively correlated with stem slenderness. Negative values of correla-
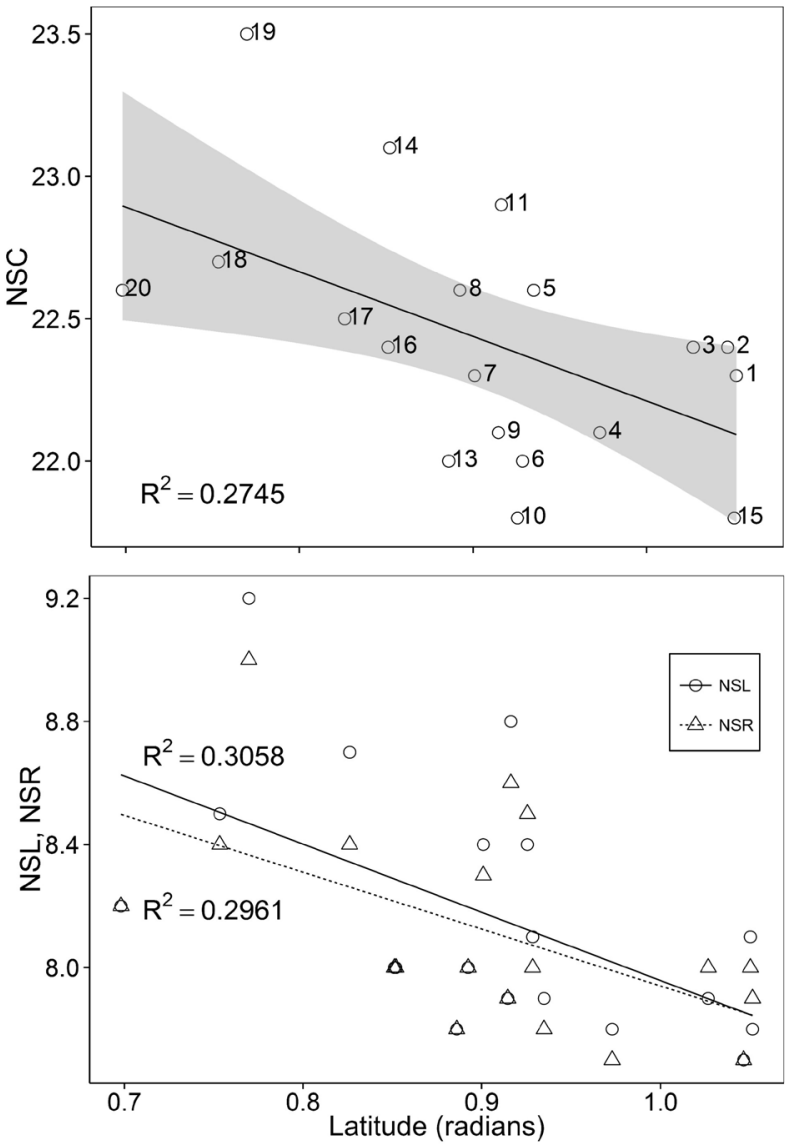

Fig. 3. Relationship between latitude of provenance and needle traits (NSC, NSR and NSL) for 19 populations of Scots pine examined at the site in Supraśl. Shading indicates $95 \%$ confidence region for regression line

tion coefficients indicated that an increase in values of growth traits was associated with decreasing proportion of polymorphic loci in the six enzymatic loci studied in Prus-Głowacki (1998).

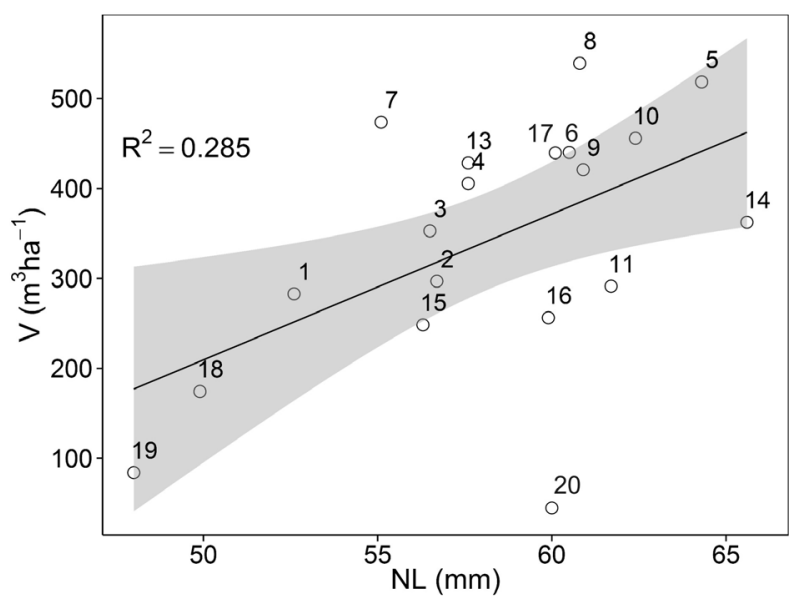

Fig. 4. Relationship between needle length (NL) and stand volume (V) for 19 populations of Scots pine examined at the site in Supraśl. Shading indicates $95 \%$ confidence region for regression line 


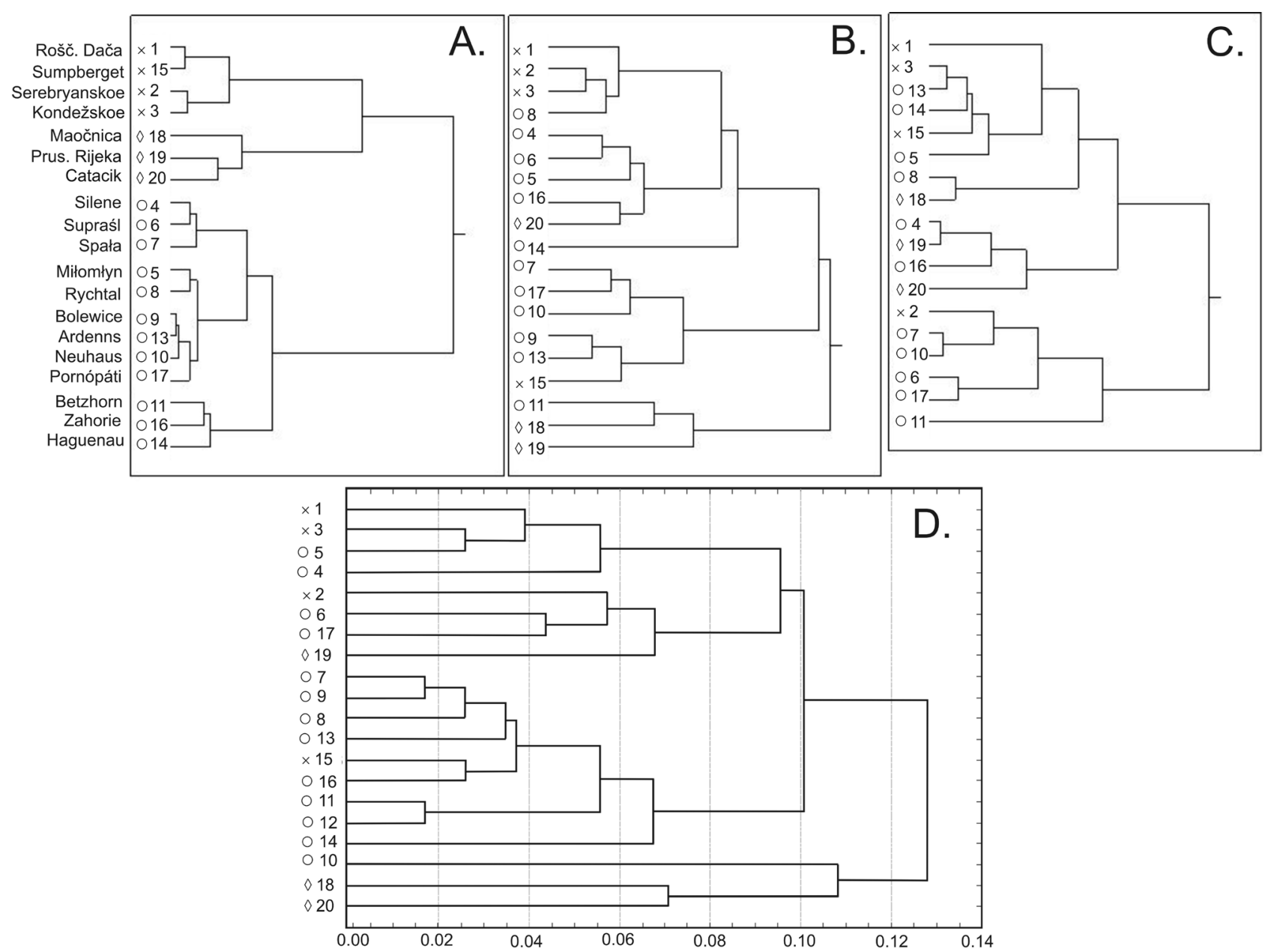

Fig. 5. Dendrograms of distances among 19 Scots pine populations obtained with the Ward's method based on growth traits (A. this study), needle morphological traits data at the site in Supraśl (B. Androsiuk et al. 2011), and enzyme polymorphism parameters for the same set of populations at the site in Kórnik (C. Prus-Glowacki 1998). Plot D. shows the UPGMA grouping of populations at the Supraśl site based on the Nei's genetic distance (reproduced from Androsiuk and Urbaniak 2014, with permission). Markers correspond to the three distinguished groups of populations $\times$ northern, o central and $\diamond$ southern

Needle traits were correlated with longitude and latitude of populations' origin. The number of stomata per $2 \mathrm{~mm}$ of needle length on the flat side (NSF) was positively correlated with longitude (Table 2, Fig. 2). The number of stomata per $2 \mathrm{~mm}$ on the convex side (NSC) and the number of serrations per $2 \mathrm{~mm}$ at left and right needle margins (NSL and NSR) were correlated negatively with latitude (Table 2, Fig. 3). Needle length, similarly to tree height and diameter, showed a nonlinear relationship with latitude, but of a much lower strength $\left(\mathrm{R}^{2}=0.24\right.$, not shown). Among the studied needle traits the needle length correlated the strongest and positively with $\mathrm{D}_{13}$, tree height, basal area and stand volume (Table 2). The Catacik population shows the greatest deviation from the regression between needle length and stand volume (Fig. 4). Despite having relatively long needles it reached the smallest stand volume, which resulted from the low number of surviving trees at the age of measurement. When this population was excluded from regression, the $\mathrm{R}^{2}$ value has improved to the value of 0.47 (Fig. 4).

The clustering of populations based on diameter, tree height and survival revealed the existence of three groups of populations - one including northern provenances from Russia and Sweden, the other including three southernmost populations, and the last one, including all remaining provenances (Fig. 5). The values of $D_{13}$ and tree height were greater for the "central" cluster than for the other two, but survival rate was greatest for the "northern" group. There was no correspondence between clustering of populations based on growth traits and morphological and biochemical or molecular markers (Fig. 5). When needle traits were used, some similarities may be found, namely in the fact that parts of the "southern" and "northern" groups were somewhat distinct, but the differences between those two groupings were marked (Fig. $5 \mathrm{~A}$ and B). The grouping with the use of enzymatic or molecular markers did not over- 
lap with that on growth traits, and the two groupings based on different types of genetic markers did not correspond to each other (Fig. 5).

\section{Discussion}

In this paper we report significant variation in growth traits and survival among 19 populations of Scots pine growing at the test site in the northeastern Poland. Compared to the earlier results obtained at this research site, the leading provenance in terms of height growth changed from the provenance Ardenns in 1998 (Barzdajn, 2000) to the provenance Bolewice in 2005 (Barzdajn, 2008), and to Rychtal in the current investigation. In terms of tree diameter the leading provenance changed from Rychtal in 2005 to Hagenau. The highest productivity, as determined by the basal area and stand volume, was found for the Polish provenances Rychtal and Miłomlyn. The population from Bolewice, dominant in the previous period (Barzdajn, 2008), ranked outside the group of the most productive populations in the present study.

The relationship between tree dimensions and the latitude of population origin in our study was well described by a graph of quadratic parabola. Similar results were obtained by Kohlstock and Schneck (1998) at the experimental site in Waldsieversdorf, as well as by Oleksyn and Rachwał (1994) at the site in Niepołomice, when analyzing the relationship between tree height and latitude in this same set of Scots pine populations. At the test site in Kórnik, the breast height diameter, tree height and biomass accumulation were significantly correlated with latitude, with maxima reached by populations originating from the latitudes close to the experimental site (Oleksyn et al., 1999, 2000). At that same site, Scots pine populations from southern and northern Europe had lower growth rates and completed their leader shoot growth earlier compared to the populations from the "central" latitudes (Oleksyn et al., 2001). On the basis of results collected from the site in Sękocin, Matras (1998) concluded that the greatest values of growth traits were found for Scots pine populations originating from latitudes between $49^{\circ} \mathrm{N}$ and $53^{\circ} \mathrm{N}$ - in this respect we reached almost identical conclusions in our study based on results obtained in Supraśl.

Clustering of populations based on diameter, tree height and survival has clearly divided our populations into three latitudinal groups: northern, central and southern. This clustering in Supraśl corresponds very well to a division of the same set of provenances at the Kórnik site by Oleksyn et al. (2001), although in the earlier papers (Oleksyn et al., 1999; Oleksyn et al., 2000) the Latvian population from Silene was classified as "northern". Similarly, Androsiuk and Urbaniak (2011) classified the Silene provenance as northern and the Hungarian population Pornóapáti as southern, but their grouping of populations was set a priori. In contrast, based on our analysis of growth traits, both the Silene and Pornóapáti provenances belonged definitely to the group of central populations. This indicates, however, that division between the northern and central populations is not clear-cut, and more populations from that region would be needed to allow better resolution of the observed pattern of variation.

The high values of growth traits observed in our study for populations originating from the latitudinal band between $49^{\circ} \mathrm{N}$ and $54^{\circ} \mathrm{N}$ confirm the good adaptation and growth of Polish provenances, which was also reported in other comparative tests (Giertych, 1993). At our experimental site differences in productivity measured by stand volume were as high as $92 \%$ (between provenances Rychtal and Catacik). Within the range of the "central" populations, the differences amounted to as much as over 52\% (Rychtal vs. Zahorie). Within only the Polish provenances the differences in productivity reached up to $22 \%$ (Rychtal vs. Bolewice), but they were not statistically significant. The difference in stand volume between the most productive provenance from Rychtal and the local population Supraśl (6) was $18 \%$.

Low productivity observed at our research site for Scots pine populations from southern Europe was associated with their low survival rate. Among those populations with low survival rate were also the provenances Zahorie from Slovakia and Betzhorn from Germany. Already in earlier reports (Barzdajn, 2000, 2008) it was found that these populations were not adapted to the environment of the Supraśl site. In contrast, a different response to the environmental conditions was found for the northern provenances (Russian - 1-3, Latvian - 4 and Swedish -15). They had high survival rates, which even at small tree dimensions resulted in productivity of those populations comparable to the mean for the experimental site. In fact, these northern provenances had survival rate greater than the group of central populations, which contrasts with the observation at the site in Kórnik, where the central populations had the greatest survival (Oleksyn et al., 1999). These observations may be important in the light of population adaptation to climate change, especially with regard to "assisted migration" (O’Neill et al., 2008). Northern populations showed a lower resistance and resilience to drought within the same set of provenances at one of the two sites in Germany investigated by Taeger et al. (2013), but they had similar recovery after drought. Results of Taeger et al. (2013) highlight the importance of genotype $\times$ environment interaction in response to extreme climatic events, 
which have to be considered in the interpretation of population adaptation to climate change. Our results clearly show that the southern populations moved so far north suffered too much of a climatic transfer. On the other hand, good survival of northern populations in a milder environment of our research site, as compared to their native climate, indicates that there is some potential within those populations to adapt to changes in climate corresponding to that transfer. However, results from the other site with even milder climate (Oleksyn et al., 1999) implicate that a greater change in climate may pose a threat to survival for those northern populations. Nonetheless, high survival itself will not provide for lower growth and smaller productivity of these provenances as compared to the ones originating a little further south.

All these results indicate that there was a large variation among tested populations in growth at the examined test site, and that pattern of variation in growth and productivity, but not in survival, was similar to those obtained at other sites of this series of provenance experiments. The ranks of examined provenances may change with age within the broadly defined latitudinal zones, but the ranking of those zones remains stable. The local provenance was in the group of well-growing origins, but was not the best.

In our study we compared the grouping of the set of Scots pine populations based on examined growth traits with the groupings based on published data on needle traits and genetic markers. Grouping of populations based on enzymatic (Prus-Głowacki, 1998) and molecular markers (Androsiuk \& Urbaniak, 2014) did not correspond to the clustering based on growth traits or that based on needle traits. Growth traits are controlled by many genes, and thus it is highly unlikely that variation found in a small set (given a huge genome size of Pinaceae (Neale \& Kremer, 2011)) of random markers would closely correspond to variation in growth and survival. More thoroughly organized experiments using candidate gene-based approach would be required for genetic association studies (e.g. Gonzalez-Martinez et al., 2007; Tian et al., 2014). The allozymes and especially RAPD markers are neutral genetic markers, whereas growth and needle traits may better reflect adaptive variation. Moreover, the enzyme polymorphism parameters we used in our analysis were obtained at the different site in Kórnik, although on the same set of populations. At those two sites (Supraśl and Kórnik) populations were grouped differently even with the use of the same markers (Androsiuk \& Urbaniak, 2014).

Among the parameters of variation for enzymatic loci only the genotype polymorphism index $(\mathrm{Pg})$ showed significant negative correlations with growth traits, and other parameters seemed to be unrelat- ed to variation in growth. In European beech (Fagus sylvatica (L.)) Gömöry et al. (2013) found an association between phenotypic variation in quantitative traits, including growth and survival, and the effective number of alleles and expected heterozygosity using 12 allozyme loci, but no association between the total number of alleles and quantitative traits variation. In Scots pine the large variation among populations was found in bud set (quantitative trait), but low among-population variation in different classes of markers (Karhu et al., 1996). Similarly, low correlations between molecular and quantitative variation, especially for life-history traits, were found in a range of organisms investigated in a meta-analysis by Reed and Frankham (2001). Correlations based on heritabilities, and thus on the estimates of additive variance, were particularly low (Reed \& Frankham, 2001). It is likely that in our study such correlations would be of similar order, however, family structure would be required to obtain estimates of additive variance. At any rate, using enzymatic and molecular markers may lead to different picture of population differentiation, and did not correspond to variation in growth traits found among Scots pine populations investigated in our study.

We also investigated correlations between our growth traits and the published data on needle traits in a search for morphological markers associated with growth that may be easy to assess. This was based on the premise that needle traits showing strong correlations with growth or stem quality traits, could be used as easy morphological markers in breeding programs, even if those correlations were lacking well-defined biological reasoning. Obviously, the persistence of such needle traits over time and across environments would need to be determined, in order to confirm their usefulness as such markers. However, in our study significant correlations were found only between growth traits and needle length, and the strength of those correlations was only average. The significance of other correlations with needle traits, e.g. between the number of serrations and survival, or between the number of stomata and stem slenderness, resulted from cross-correlations between those traits and latitude. As could be expected from the observed structure of correlations, the clustering of populations varied depending on whether it was based on growth traits or needle morphology. Although Androsiuk et al. (2011) distinguished between the northernmost and southernmost populations using the discriminant analysis, the grouping of populations based on needle traits was completely different from that on growth traits when populations were clustered with the Ward method. Given that, we conclude that the utility of needle traits as morphological markers of productivity is questionable. Moreover, needle traits exhibit rather large en- 
vironmental variation. Even needle length, which showed the strongest correlation with growth traits, varied between the two sites in Kórnik and Supraśl (Androsiuk et al., 2011). The resolution of needle traits is too low to be used as such markers, and they may provide only relative differentiation among examined populations.

\section{Concluding remarks}

The tested populations of Scots pine differed in terms of growth and adaptation at the examined research site. Tree dimensions, survival rate, and thus stand volume varied to a degree that is of economic importance.

The relationship between growth traits and latitude was described by a parabola with a vertex within the range between $49^{\circ} \mathrm{N}$ and $53^{\circ} \mathrm{N}$. Populations originating north or south of that zone reached lower values of the described traits.

Scots pine of southern provenances showed poor adaptation to the site conditions in Supraśl and exhibited high mortality. Northern provenances showed high survival rates, but only average productivity.

All Polish provenances included in this trial were distinguished by their high productivity, which indicates their high value for tree breeding and operational forestry.

Needle morphological traits were not appropriate as markers of productivity. Population differentiation based on needle traits, and biochemical or molecular genetic markers did not correspond to the pattern of variation found in growth traits among the examined seed sources of Scots pine.

\section{References}

Androsiuk P, Kaczmarek Z \& Urbaniak L (2011) The morphological of needles as markers geographical differentiation in European Pinus sylvestris populations. Dendrobiology 65: 3-16.

Androsiuk P \& Urbaniak L (2014) Genetic variability of Pinus sylvestris populations from IUFRO 1982 provenance trial. Dendrobiology 71: 23-33.

Andrzejewski K, Kowalkowski W \& Rzeźnik Z (1994) Variability of growth and qualitative features of 10-years old Scots pine (Pinus sylvestris L.) of 20 European provenances: Scots pine breeding and genetics Proceedings of IUFRO S.2.02.18 Symposium Lithuania 13-17 September 1994, pp. 24-28.

Barzdajn W (2000) Doświadczenie proweniencyjne nad zmiennością sosny zwyczajnej (Pinus sylvestris L.) serii IUFRO 1992 w Nadleśnictwie Supraśl. Sylwan 6: 41-52.
Barzdajn W (2008) Wyniki 24-letniego doświadczenia proweniencyjnego $z$ sosną $\mathrm{w}$ Nadleśnictwie Supraśl. Sylwan 152: 21-29.

Białobok S (1970) Rozmieszczenie w Eurazji: Sosna zwyczajna. Nasze drzewa leśne (ed. by $\mathrm{S}$ Bialobok) PWN Warszawa, Poznań, pp. 78-85.

Boratyński A (1993) Systematyka i geograficzne rozmieszczenie: Biologia sosny zwyczajnej (ed. by S Białobok, A Boratyński \& W Bugała) Sorus, Poznań-Kórnik, pp. 45-69.

Broda J (1993) Sosna w czasach historycznych: Biologia sosny zwyczajnej (ed. by S Białobok, A Boratyński \& W Bugała) Sorus, Poznań-Kórnik, pp. 17-32.

Czuraj M (1991) Tablice miąższości kłód odziomkowych i drzew stojących. PWRiL, Warszawa.

Giertych M (1979) Summary of results on Scots pine (Pinus sylvestris L.) height growth in IUFRO provenance experiments. Silvae Genetica 28: 136-152.

Giertych M (1993) Zmienność proweniencyjna: Biologia sosny zwyczajnej (ed. by S Białobok, A Boratyński \& W Bugała) Sorus, Poznań-Kórnik, pp. 325-339.

Giertych M (1997) Zmienność proweniencyjna sosny zwyczajnej (Pinus sylvestris L.) w Polsce. Sylwan 141: 5-20.

Giertych M \& Oleksyn J (1992) Studies on genetic variation in Scots pine (Pinus sylvestris L.) coordinated by IUFRO. Silvae Genetica 3: 133-143.

Gömöry D, Comps B, Paule L \& von Wühlisch G (2013) Allozyme and phenotypic variation in beech (Fagus sylvatica L.): Are there any links? Plant Biosystems 147: 265-271.

Gonzalez-Martinez SC, Wheeler NC, Ersoz E, Nelson CD \& Neale DB (2007) Association genetics in Pinus taeda L. I. Wood property traits. Genetics 175: 399-409.

Karhu A, Hurme P, Karjalainen M, Karvonen P, Karkkainen K, Neale D \& Savolainen O (1996) Do molecular markers reflect patterns of differentiation in adaptive traits of conifers? Theoretical and Applied Genetics 93: 215-221.

Kohlstock N \& Schneck V (1998) IUFRO provenance trial of Scots pine (Pinus sylvesris L.) at Waldsieversdorf 1982-1994: Scots pine breeding and genetics. Proceedings of IUFRO S.2.02.18 Symposium, Lithuania 13-17 September 1994, pp. 29-36.

Matras J (1998) Clinal differences in growth and qualitative features of Scots pine (Pinus sylvestris L.) European provenances: Scots pine breeding and genetics. Proceedings of IUFRO S.2.02.18 Symposium, Lithuania 13-17 September 1994, pp. 46-53.

Neale DB \& Kremer A (2011) Forest tree genomics: growing resources and applications. Nature Reviews Genetics 12: 111-122. 
Oleksyn J (1988) Report on the IUFRO-1982 provenance experiment on Scots pine (Pinus sylvestris L.). Arboretum Kórnickie 33: 211-229

Oleksyn J \& Rachwał L (1994) Wzrost europejskich populacji sosny zwyczajnej (Pinus sylvestris L.) $\mathrm{W}$ doświadczeniu proweniencyjnym SP-IUFRO-1982 w Puszczy Niepołomickiej. Sylwan 9: 57-69.

Oleksyn J, Tjoelker MG \& Reich PB (1998) Adaptation to changing environment in Scots pine Population across a Latitudinal Gradient. Silva Fennica 32: 129-140.

Oleksyn J, Reich PB, Tjoelker MG \& Chałupka W (1999) Differential above- and below-ground biomass accumulation of European Pinus sylvestris Populations in 12-year-old Provenance Experiment. Scandinavian Journal of Forest Research 14: 7-17.

Oleksyn J, Reich PB, Rachwał L, Tjoelker MG \& Karolewski P (2000) Variation in aboveground net primary production of diverse European Pinus sylvestris populations. Trees 14: 415-421.

Oleksyn J, Reich PB, Tjoelker MG \& Chałupka W (2001) Biogeographic differences in shoot elongation pattern among European Scots pine populations. Forest Ecology and Management 148: 207-220.

Oleksyn J, Tjoelker MG \& Reich PB (1992) Growth and biomass partitioning of populations of European Pinus sylvestris L. under simulated $50^{\circ}$ and $60^{\circ} \mathrm{N}$ daylengths: evidence for photoperiodic ecotypes. New Phytologist 120: 561-574.

O'Neill GA, Ukrainetz NK, Carlson MR, Cartwright CV, Jaquish BC, King JN, Krakowski J, Russell JH, Stoehr MU, Xie C \& Yanchuk AD (2008) Assist- ed migration to address climate change in British Columbia: recommendations for interim seed transfer standards. Technical Report 048. B.C. Ministry of Forests and Range, Research Branch, Victoria, B.C. Canada.

Prus-Głowacki W (1998) Genetic differentiation of Pinus sylvestris L. in Europe: Scots pine breeding and genetics Proceedings of IUFRO S.2.02.18 Symposium, Lithuania 13-17 September 1994, pp. 63-70.

Reed DH, Frankham R (2001) How closely correlated are molecular and quantitative measures of genetic variation? A meta-analysis. Evolution 55: 1095-1103.

Shutyaev AM \& Giertych M (2003) Scots pine (Pinus sylvestris L.) in Eurasia - a map album of provenance site interactions. Institute of Dendrology, Kórnik.

Stephan BR \& Liesebach M (1996) Results of the IUFRO 1982 Scots pine (Pinus sylvestris L) provenance experiment in southwestern Germany. Silvae Genetica 45: 342-349.

Taeger S, Zang C, Liesebach M, Schneck V \& Menzel A (2013) Impact of climate and drought events on the growth of Scots pine (Pinus sylvestris L.) provenances. Forest Ecology and Management 307: 30-42.

Tian J, Chang M, Du Q, Xu B \& Zhang D (2014) Single-nucleotide polymorphisms in PtoCesA7 and their association with growth and wood properties in Populus tomentosa. Molecular Genetics and Genomics 289: 439-455.

World Reference Base for soil resources (2006) 2nd edition. World Soil Resources Reports No. 103. FAO, Rome. 